\title{
PERBANDINGAN STEGANALISIS SINYAL WICARA BERFORMAT .WAV ANTARA METODE ANALISIS CEPSTRAL DAN MEL-FREQUENCY CEPSTRAL COEFFICIENT (MFCC)
}

\author{
Kevin Putra Dirgantoro ${ }^{1}$, Bambang Hidayat $^{2}$, Nur Andini $^{3}$ \\ 1, 2, ${ }^{3}$ Fakultas Teknik Elektro, Universitas Telkom \\ ${ }^{1}$ kevputrad@telkomuniversity.ac.id, ${ }^{2}$ bhidayat@telkomuniversity.ac.id, \\ 3 nurandini@telkomuniversity.ac.id
}

\begin{abstract}
Abstrak
Teknik menyembunyikan pesan rahasia ke dalam suatu data tertentu atau yang biasa dikenal dengan steganografi mengalami perkembangan yang sangat pesat. Namun, ternyata metode penyembunyian pesan ini juga menimbulkan masalah, di antaranya pihak-pihak yang tidak bertanggung jawab menggunakan teknik tersebut untuk kegiatan kriminalitas. Oleh karena itu, diperlukan teknik untuk mendeteksi pesan tersembunyi di dalam suatu data. Teknik tersebut dikenal dengan istilah steganalisis. Pada penelitian ini, dilakukan analisis terhadap berkas sinyal wicara yang berformat .wav, dengan menggunakan dua metode, yaitu analisis cepstral dan $\mathrm{Mel}$ Frequency Cepstral Coefficient (MFCC). Perbandingan dari kedua metode ini dilakukan untuk mengetahui metode mana yang lebih baik untuk mendeteksi data memiliki pesan rahasia atau tidak. Nilai akurasi yang didapat dengan menggunakan 45 data latih dan uji untuk metode analisis cepstral yaitu sebesar 51,11\%, sedangkan untuk MFCC sebesar $\mathbf{7 7 , 7 8 \%}$. Nilai akurasi tersebut didapat dari ciri statistik yang terdiri dari nilai kurtosis, skewness, dan standard deviation yang dihasilkan dari kedua metode, dengan menggunakan metode klasifikasi Support Vector Machine (SVM).
\end{abstract}

Kata Kunci: analisis cepstral, Mel-Frequency Cepstral Coefficient (MFCC), steganalisis WAV

\begin{abstract}
A technique to hide secret message into a specific data or known as steganography, having a rapid progress. Unfortunately, this phenomena also triggers new problem: many of unresponsible parties use this method for criminal activity. Therefore, a technique for detecting a hidden message in a specific data is necessary. This technique is known as steganalysis. In this research, an analysis of speech signal file with .wav format was performed using two different methods: analysis cepstral and Mel-Frequency Cepstral Coefficient (MFCC). The methods were compared in order to know which method is better for hidden message detection. The accuration value for ceptral analysis that using 45 train and test file is $51,11 \%$, meanwhile for MFCC is $\mathbf{7 7 , 7 8 \%}$. The accuration values were obtained from statistical features, that consist of kurtosis, skewness, and standard deviation from both methods, using Support Vector Machine (SVM) for its classification.
\end{abstract}

Key Words: cepstral analysis, MFCC, statistics, steganalysis, SVM, .WAV

\section{Pendahuluan}

Perkembangan teknologi telekomunikasi semakin maju seiring dengan berjalannya waktu. Karena adanya telekomunikasi, hubungan komunikasi masih dapat berlangsung walaupun terpisahkan oleh jarak. Dalam berkomunikasi jarak jauh, terkadang ada pesan terkirim yang dapat diakses publik, namun ada juga yang bersifat rahasia demi menjaga privasi. Pengiriman pesan secara rahasia ini telah menjadi suatu kesenian yang memang tidak semua orang dapat melakukannya, yang disebut dengan Steganografi. Pesan rahasia yang dikirim melalui cara steganografi dapat bermacam-macamjenisnya, misalkan, diubah menjadi bahasa yang sulit dimengerti, menggunakan mesin (salah satunya mesin enigma)atau dengan menyisipkan suatu pesan rahasia pada suatu media, baik gambar, audio bahkan video. [1]

Steganografi sangat dibutuhkan untuk mengirimkan pesan yang sangat rahasia, misalnya antar kepala negara yang bertukar informasi rahasia dengan media gambar. Namun, bagaimana jika steganografi ini dilakukan oleh orang yang tidak bertanggung jawab? Pengembangan teknik untuk memecahkan atau membongkar informasi yang telah disisipkan pada pesan rahasia menggunakan 


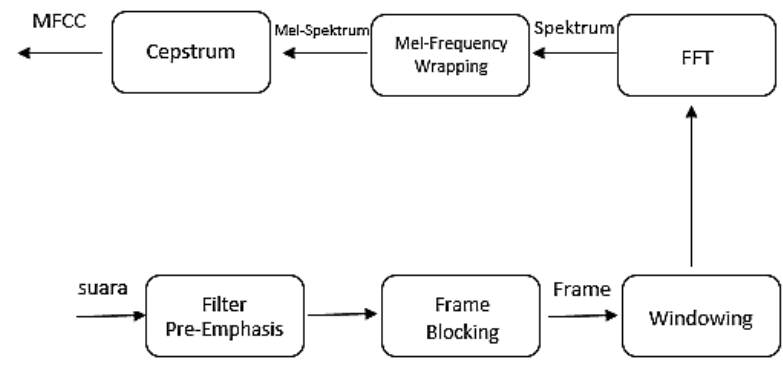

Gambar 1. Blok Diagram MFCC

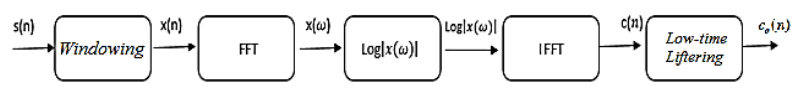

Gambar 2. Blok Diagram Analisis Cepstral

teknik steganografi juga diperlukan, yang disebut dengan steganalisis.[2]

Pada penelitian ini, analisis perbandingan akurasi steganalisis menggunakan dua metode dikaji. Media yang digunakan adalah sinyal wicara (speech), karena sinyal ini merupakan media yang sering disisipkan oleh pesan rahasia. Sedangkan format berkas speech yang digunakan adalah .wav , karena sering dipakai kebanyakan orang, memiliki struktur yang sederhana dan kualitas suaranya yang baik [3]. Metode yang dibandingkan yaitu metode analisis Cepstral dan Mel-Frequency Cepstral Coefficient (MFCC), dengan pertimbangan keduanya memiliki mekanisme kerja yang relatif sama, sehingga patut diteliti lebih jauh metode mana yang lebih efisien dan memiliki kualitas yang lebih baik. Nilai akurasi yang didapat merupakan nilai root mean square (rms) dari setiap frame sinyal wicara yang menghasilkan distribusi error yang dapat dicirikan dengan kurtosis, skewness, dan standard deviation.

Sinisuka dkk, telah dilakukan steganalisis menggunakan metode statistik Mel-Frequency Cepstral Coefficient (MFCC) yang menggunakan klasifikasi Support Vector Machine (SVM)[4]. Hasil akurasi yang didapatkan berdasarkan jumlah sisipan, yaitu sebesar $43,75 \%$ untuk sisipan yang sedikit, sedangkan untuk sisipan yang banyak nilai akurasinya mencapai $50 \%$.

Gambar 1 menjelaskan bagaimana cara kerja metode MFCC untuk mendapatkan ekstraksi ciri MFCC. Hal pertama yang dilakukan adalah melakukan pre-emphasis menggunakan orde pertama Finite Impuls Response (FIR) dan high pass filter (HPF), yang didasari oleh hubungan antara masukan dan keluaran dalam domain waktu [5]. Kemudian dilakukan frame blocking dengan menggunakan sistem overlap, yang bertujuan untuk meminimalisir hilangnya ekstraksi ciri [6]. Setelah sinyal dibuat dalam bentuk frame, setiap frame dikalikan dengan window hanning, untuk menghindari terjadinya discontinuities [5]. Kemudian dilakukan Fast Fourier
Transform (FFT), untuk mengubah sinyal dari domain waktu ke domain frekuensi.

Pada proses Mel-Frequency wrapping ini, filterbank yang digunakan terdiri dari sepasang Band Pass Filter (BPF),yang kondisi bandwidth dan spacing-nya mendekati critical band-nya. Selain itu juga, bagian tengah dari frequency filter tersebut digunakan untuk meng-cover frekuensi-frekuensi penting untuk persepsi sinyal wicara [5]. Pada tahap terakhir, hasil mel spektrum dikonversikan kembali ke dalam domain waktu menggunakan invers FFT dengan fungsi Discrete Cosine Transform (DCT). Hasil akhir dari perhitungan tersebut dinamakan Mel-Frequency Cepstral Coefficient (MFCC), yang merupakan representasi dari spektrum sinyal wicara [7].

Telah dilakukan juga penelitian yang menggunakan metode analisis Cepstral olehRao dkk, namun penelitian yang dilakukan berfokus pada pendekatan peningkatan kata bicara dua tahap berbasis data yang pada stage kedua sisa dari noise di-suppress dan didapatkan peningkatan kualitas suara $20 \%$, pada kondisi noise tertentu [8].

Gambar 2 merupakan gambar dari blok diagram analisis cepstral, dengan masukan $s(n)$ merupakan sequence dari sinyal wicara yang digunakan. Sinyal sequence tersebut kemudian dikalikan dengan hanning window dan menghasilkan $x(n)$ yang merupakan sinyal windowed sequence. Nilai sinyal $x(n)$ tersebut akan dilakukan proses FFT dan menghasilkan $x(\omega)$ sebagai spektrum dari $x(n)$. Log magnitude spectrum didapatkan dengan melakukan proses logaritma dari spektrum $x(\omega)$. Dilakukan invers FFT untuk mentransformasikan kembali sinyal ke domain waktu, namun pada invers FFT log spectra ditransformasikan ke domain quefrency yang sama percis dengan domain waktu. Pemisahan dapat dilakukan dengan melakukan invers FFT kombinasi log spectra dari eksitasi dan karakteristik filter dari vocal tract secara linear [9].

Terdapat pula proses liftering yang merupakan operasi yang serupa dengan filtering pada domain frequency. Terdapat dua macam liftering berdasarkan, yang pertama yaitu high-time liftering yang memiliki fungsi untuk mendapatkan karakteristik ekstasi dari glotis, sedangkan yang kedua yaitu, low-time liftering yang berfungsi untuk mendapatkan karakteristik vocal tract yang biasa digunakan untuk voice recognition [9]. Pada penelitian ini digunakan low time liftering.

\section{Pembahasan}

Dalam penelitian ini, dilakukan pengujian akurasi performasi sistem dengan menggunakan dua metode yang dibandingkan yaitu analisis cepstral dan MFCC. Perbandingan kedua metode tersebut berdasarkan nilai akurasi dalam mengklasifikasi berkas asli, stego ataupun noise. Terdapat berkas sinyal wicara dengan durasi 10 
detik sebanyak 15 berkas dengan ukuran tiap berkasnya $937 \mathrm{~Kb}$ dengan bit rate 768 Kbps. Dari 15 berkas sinyal wicara asli, diambil 5 sinyal wicara pertama yang disisipkan oleh pesan rahasia dengan metode Discrete Cosine Transform (DCT), Discrete Wavelet Transform (DWT) dan Least Significant Bit (LSB) yang masing-masing metode disisipkan pesan dengan ukuran 359 karakter.

Isi pesan steganografi yang digunakan yaitu: "Steganografi biasa didefinisikan sebagai seni menyembunyikan informasi rahasia dalam pesan lain yang tampaknya tidak berbahaya sehingga mencegah adanya tindakan pendeteksian pesan tersembunyi”. Dibandingkan teknik enkripsi lain, steganografi merupakan teknik yang lebih efektif untuk meningkatkan keamanan pesan selama proses transfer data.

Dengan 5 sinyal wicara yang sama, dilakukan penambahan noise yang terdiri dari Additive White Gaussian Noise (AWGN), noise gaussian, dan noise echo. Sehingga total berkas sinyal wicara yang digunakan yaitu 45 berkas, 15 berkas asli, 15 berkas stego dan 15 berkas noise. Noise gaussian dibuat dalam bentuk distribusi normal dalam domain waktu dengan nilai domain waktu rata-rata yaitu nol, sedangkan AWGN pada dasarnya sinyal noise yang ditambahkan bersifat aditif (additive), berwarna putih (white) dan terdistribusi normal (gaussian). Putih mengacu pada gagasan bahwa sinyal tersebut memiliki kekuatan yang seragam di seluruh pita frekuensi. Sedangkan noise echo yaitu dilakukan penambahan gema yang berulang pada berkas sinyal. Tabel 1 menunjukkan level Signal to Noise Ratio (SNR) menggunakan tiga jenis noise yang sudah disebutkan sebelumnya. Nilai SNR untuk tiap metode noise berbeda-beda dari rentang $10 \mathrm{~dB}$ hingga $25 \mathrm{~dB}$. Penggunaan level SNR yang berbeda-beda untuk membuktikan kerusakan yang terjadi pada sinyal asli.

Desain pemodelan sistem pada penelitian ini adalah suatu sistem perancangan pengolahan sinyal audio digital berupa berkas sinyal wicara (speech). Konfigurasinya terdiri dari tiga tahap, yaitu: representasi berkas bicara, pengklasifikasian, dan perbandingan hasil, seperti ditunjukkan pada Gambar 3.

Pada tahap pengklasifikasian, dilakukan proses pelatihan terlebih dahulu terhadap data latih kemudian dilakukan pengujian berdasarkan data yang telah dilatih terhadap data uji. Pada tahap pelatihan, hasil dari sinyal wicara yang diolah oleh kedua metode yang dipakai, akan ditarik kesimpulan sementara dari hasil data tersebut, yang dinamakan data latih. Data latih akan dijadikan sebagai database latih untuk digunakan pada tahap pengujian.

Tahap pelatihan metode analisis cepstral dapat dilihat pada Gambar 4(a). Setelah memilih sinyal wicara latih, dilakukan framing tanpa menggunakan overlap pada sinyal tersebut. Proses framing tersebut akan
Tabel 1. Nilai SNR pada Speech Noise

\begin{tabular}{|c|c|}
\hline Jenis Berkas & Nilai SNR \\
\hline AWGN6 & $14,8707 \mathrm{~dB}$ \\
\hline AWGN7 & $15,5876 \mathrm{~dB}$ \\
\hline AWGN8 & $10,7838 \mathrm{~dB}$ \\
\hline AWGN9 & $12,9772 \mathrm{~dB}$ \\
\hline AWGN10 & $14,9936 \mathrm{~dB}$ \\
\hline Gaussian6 & $25,3647 \mathrm{~dB}$ \\
\hline Gaussian7 & $24,4923 \mathrm{~dB}$ \\
\hline Gaussian8 & $23,2333 \mathrm{~dB}$ \\
\hline Gaussian9 & $24,0746 \mathrm{~dB}$ \\
\hline Gaussian10 & $24,9097 \mathrm{~dB}$ \\
\hline Echo6 & $14,9570 \mathrm{~dB}$ \\
\hline Echo7 & $16,6110 \mathrm{~dB}$ \\
\hline Echo8 & $20,7146 \mathrm{~dB}$ \\
\hline Echo9 & $19,6350 \mathrm{~dB}$ \\
\hline Echo10 & $16,9909 \mathrm{~dB}$ \\
\hline
\end{tabular}

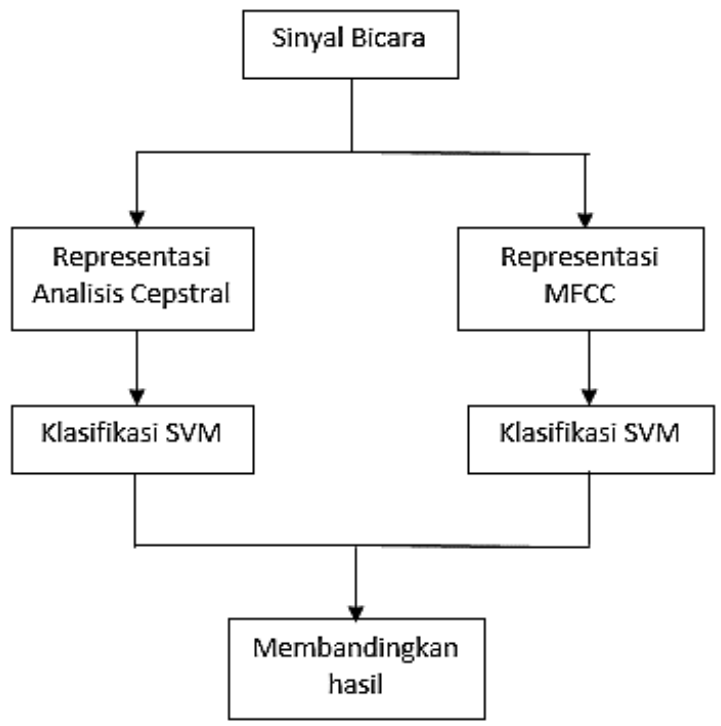

Gambar 3. Konfigurasi Umum Sistem

menghasilkan 334 frames dengan panjang satu frame-nya $30 \mathrm{~ms}$ dan jumlah samples dalam satu buah sinyal wicara sebanyak 480.000 samples, sehingga di dalam satu frame terdiri dari 1440 samples. Sedangkan untuk metode MFCC pada Gambar 4(b), dilakukan framing dengan overlap dan nilai koreksi M sebesar 100 samples, maka didapatkan jumlah frame sebanyak 4786 frames yang dalam tiap frame terdiri dari 1440 samples juga.

Setiap frame yang telah dibuat proses window kemudian diaplikasikan dengan jumlah frame-nya terdiri dari 1440 sampel. Pada metode analisis cepstral, jenis window yang paling sering digunakan adalah Hamming Window, sedangkan untuk metode MFCC jenis window 


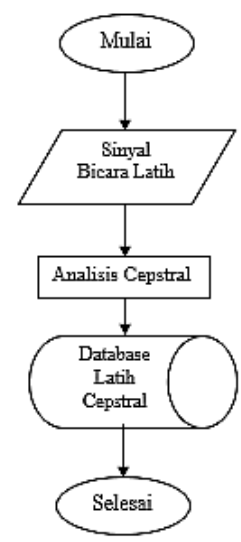

(a)

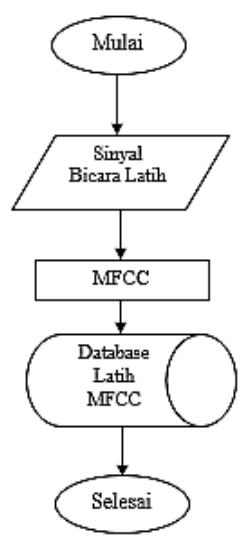

(b)

\section{Gambar 4. Tahap Pelatihan Metode Cepstral (a), dan $\operatorname{MFCC}(\mathbf{b})$}

digunakan Hanning Window. Perbedaannya terletak pada nilai koefisien window yang digunakan. Pada Hamming Window besar koefisiennya 0,54, sedangkan Hanning Window adalah 0,5. Nilai dari window yang telah dibuat dikalikan ke setiap sampel yang berada di tiap frame.

Nilai dari sinyal yang telah diberi window akan ditransformasikan dari domain waktu dalam bentuk domain frekuensi, menggunakan fungsi DFT, dengan algoritma FFT. Nilai keluaran dalam domain frekuensi ini memiliki nilai bilangan asli dan bilangan kompleks. Fungsi absolute diberlakukan kepada tiap sampel didalam frame untuk menghilangkan nilai bilangan kompleks.

Perbedaan pada kedua metode yang digunakan adalah pada MFCC. Setelah fungsi DFT dilakukan pada sinyal, akan dilakukan proses Mel-Frequency Wrapping yang dapat meniru sistem pendengaran manusia, dengan cara mengonversi frekuensi rendah dan frekuensi tinggi yang digunakan ke nilai mels. Kemudian dibentuk 20 filter yang diaplikasikan ke setiap frame. Sedangkan untuk analisis cepstral, setelah sinyal dilakukan fungsi DFT, setiap sampel di dalam frame langsung dilakukan fungsi log, begitu pula dengan sampel yang telah difilter dalam tiap frame untuk MFCC.

Tahapan terakhir, yaitu mentransformasikan kembali sinyal dari bentuk frekuensi ke domain waktu. Pada analisis cepstral digunakan fungsi invers DFT, dengan algoritma invers FFT. Transformasi pada analisis cepstral mentransformasikan sinyal ke domain frekuensi yang sangat mirip dengan domain waktu. Oleh karena itu, liftering harus dilakukan, liftering identik dengan filtering pada domain frekuensi, yang terdiri dari low-time liftering, untuk mendapatkan karakteristik vocal tract dan high-time liftering untuk mendapatkan karakteristik eksitasi glottal. Proses analisis cepstral yang digunakan adalah low-time liftering, dengan menerapkan Low Pass Filter untuk mengambil nilai pada 15 sampel pertama pada sinyal wicara. Pada MFCC, proses DCT dilakukan untuk mentransformasikan kembali sinyal dari domain frekuensi ke domain waktu sebagai fungsi invers FFT. Nilai ini yang digunakan untuk mendapatkan nilai statistik yang terdiri nilai skewness, kurtosis, dan standard deviation pada tiap frame.

Nilai-nilai statistik tersebut disimpan kedalam database, untuk selanjutnya dilakukan Support Vector Machine SVM train dan dikategorikan berdasarkan kelasnya masing-masing. Kategori yang pertama terdiri dari berkas 'Asli' dan 'Tidak Asli'. Kategori 'Tidak Asli' sendiri terdiri dari berkas stego dan noise. Untuk kategori yang kedua, berkas untuk kelas stego dan noise dipisahkan kembali dengan kategori 'Stego' dan 'Noise'.

Database dari masing-masing metode yang didapat dalam tahap pelatihan digunakan dalam proses klasifikasi, menggunakan SVM [10], untuk selanjutnya diketahui apakah sinyal wicara uji tersebut masuk ke dalam kategori berkas stego, berkas non-stego maupun berkas noise seperti ditunjukkan Gambar 5.

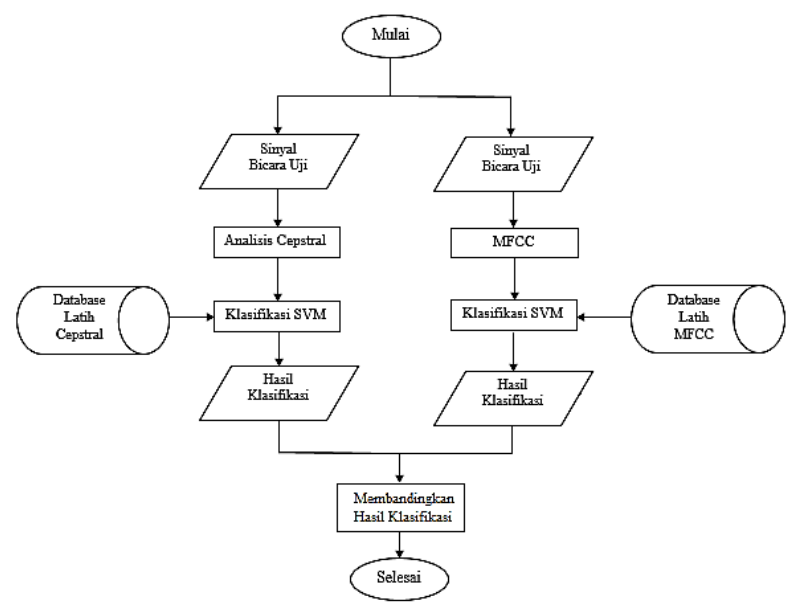

\section{Gambar 5. Tahap Pengujian}

Proses tahap pengujian sama dengan proses tahap pelatihan. Nilai-nilai statistik yang didapat dari tahap pengujian selanjutnya akan dibandingkan dengan nilai statsitik yang telah dilatih dan disimpan pada database. Output dari sinyal wicara yang diuji selanjutnya akan dikategorikan menjadi berkas 'Asli' atau 'Tidak Asli'. Jika berkas tergolong 'Tidak Asli', maka akan dilakukan klasifikasi untuk menentukan apakah berkas tersebut 'Stego' atau 'Noise'.

Perbandingan akurasi dari kedua metode yang digunakan merupakan proses terakhir untuk menentukan metode mana yang lebih baik. Untuk mengidentifikasi sebuah berkas sinyal wicara apakah memiliki pesan tersembunyi atau bahkan sudah mengalami penambahan 
noise.

Performansi sistem dapat dilihat dari hasil parameter akurasi tiap-tiap metode yang telah dibandingkan. Akurasi sendiri merupakan suatu ukuran ketepatan pada sistem dalam mengenali masukan data yang diberikan sehingga akan menghasilkan keluaran yang benar. Nilai akurasi didapatkan dari persamaan (1):

$$
\text { Akurasi }=\frac{\text { Jumlah DataBenar }}{\text { Jumlah Data Keseluruhan }} \times 100 \%
$$

Parameter-parameter pengujian yang dilakukan yaitu pengujian nilai akurasi kedua metode terhadap penggunaan window hamming dan window hanning, pengujian terhadap penggunaan jenis frame tanpa overlap dan dengan overlap, serta pengujian terhadap panjang frame yang digunakan yaitu $30 \mathrm{~ms}, 60 \mathrm{~ms}$ dan 90 ms pada kedua metode yang dibandingkan.

\subsection{Pengujian Window}

Analisis akurasi dilakukan berdasarkan jenis window yang diterapkan. Window yang digunakan yaitu Hamming dan Hanning. Perbedaan antara kedua jenis window menurut teori, yaitu pada window hamming masih memiliki kekurangan, dimana di bagian tepi-nya terjadi diskontinuitas.

Perbandingan nilai akurasi dari tiap jenis window didasarkan pada dua klasifikasi, yaitu kategori Asli atau 'Tidak Asli'. Jika "Tidak Asli", maka dikategorikan kembali menjadi 'Stego' atau 'Noise'. Spesifikasi sistem pada pengujian ini menggunakan jenis frame tanpa overlap, dengan panjang frame $30 \mathrm{~ms}$. Tabel 2 dan Tabel 3 berturut-turut menunjukkan hasil penggunaan window hamming dan window hanning.

Dapat dilihat bahwa akurasi yang lebih baik didapatkan jika sistem menggunakan window jenis hanning.

\subsection{Pengujian Jenis Frame}

Setelah diketahui bahwa penggunaan window hanning menghasilkan nilai akurasi yang lebih baik, kemudian dilakukan analisis lanjutan, mengenai pengaruh dari jenis framing dengan overlap atau tanpa overlap. Tiap berkas memiliki panjang sebesar 480.000 sampel. Karena panjang yang digunakan adalah $30 \mathrm{~ms}$, maka jumlah sampel dalam satu frame adalah sebanyak 1440 sampel.

Untuk sistem yang tanpa overlap, didapatkan jumlah frame sebanyak 334 frames. Hasil akurasi untuk sistem tanpa overlap sama dengan hasil pengujian window hanning pada pembahasan sebelumnya, seperti ditunjukkan pada Tabel 3. Nilai overlap yang baik adalah di atas $50 \%$. Pada percobaan dengan overlap ini dilakukan dengan nilai koreksi $\mathrm{M}$ sebesar 100 sampel dari tiap frame sehingga terbentuk 4786 frames. Dengan kata lain overlap yang digunakan adalah $93 \%$ dari sample tiap frame. Jumlah frame yang lebih banyak dari pada tanpa overlap dikarenakan terjadinya tumpang tindih antar sample dari frame sebelumnya dengan frame setelahnya. Fungsi dari dilakukannya overlap adalah untuk meminimalisir hilangnya ekstraksi ciri yang dibutuhkan. Hasil akurasi untuk sistem dengan overlap dapat dilihat pada Tabel 4. Dapat dilihat bahwa nilai akurasi dengan menggunakan overlap, karena dengan adanya overlap dapat meminimalisir hilangnya ekstraksi ciri.

Tabel 2. Hamming Window

\begin{tabular}{|c|c|c|}
\hline Jenis Kategori & Metode & Akurasi \\
\hline 'Asli' & Cepstral & $62,22 \%$ \\
'Tidak Asli' & MFCC & $48,89 \%$ \\
\hline 'Stego' & Cepstral & $48,89 \%$ \\
'Noise' & MFCC & $46,67 \%$ \\
\hline
\end{tabular}

Tabel 3. Hanning Window

\begin{tabular}{|c|c|c|}
\hline Jenis Kategori & Metode & Akurasi \\
\hline 'Asli' & Cepstral & $75,56 \%$ \\
'Tidak Asli' & MFCC & $75,56 \%$ \\
\hline 'Stego' & Cepstral & $51,11 \%$ \\
'Noise' & MFCC & $62,22 \%$ \\
\hline
\end{tabular}

Tabel 4. Dengan Overlap

\begin{tabular}{|c|c|c|}
\hline Jenis Kategori & Metode & Akurasi \\
\hline 'Asli' & Cepstral & $71,11 \%$ \\
'Tidak Asli' & MFCC & $86,67 \%$ \\
\hline 'Stego' & Cepstral & $46,67 \%$ \\
'Noise' & MFCC & $77,78 \%$ \\
\hline
\end{tabular}

Tabel 5. Panjang Frame $60 \mathrm{~ms}$

\begin{tabular}{|c|c|c|}
\hline Jenis Kategori & Metode & Akurasi \\
\hline 'Asli' & Cepstral & $68,89 \%$ \\
'Tidak Asli' & MFCC & $66,67 \%$ \\
\hline 'Stego' & Cepstral & $46,67 \%$ \\
'Noise' & MFCC & $46,67 \%$ \\
\hline
\end{tabular}

Tabel 6. Panjang Frame $90 \mathrm{~ms}$

\begin{tabular}{|c|c|c|}
\hline Jenis Kategori & Metode & Akurasi \\
\hline 'Asli' & Cepstral & $71,11 \%$ \\
'Tidak Asli' & MFCC & $75,56 \%$ \\
\hline 'Stego' & Cepstral & $48,89 \%$ \\
'Noise' & MFCC & $51,11 \%$ \\
\hline
\end{tabular}




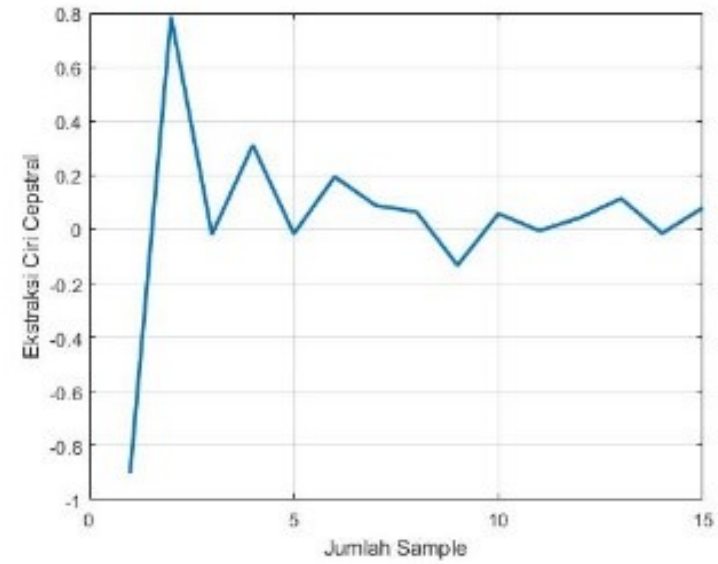

(a)

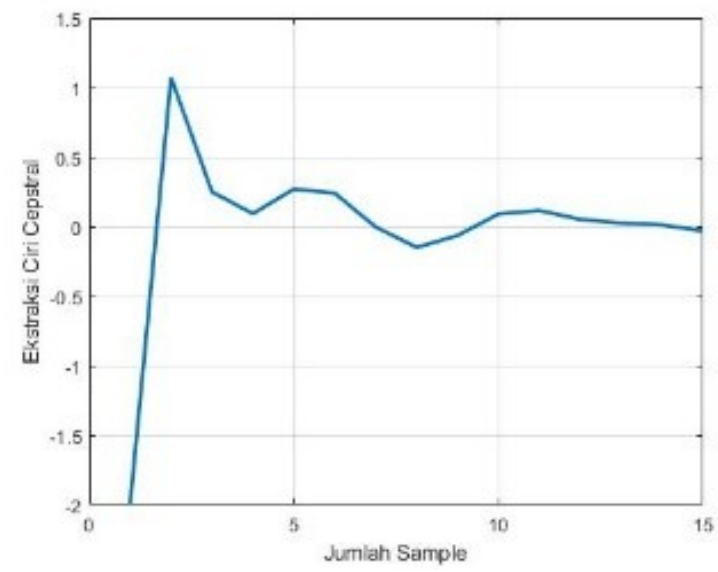

(b)

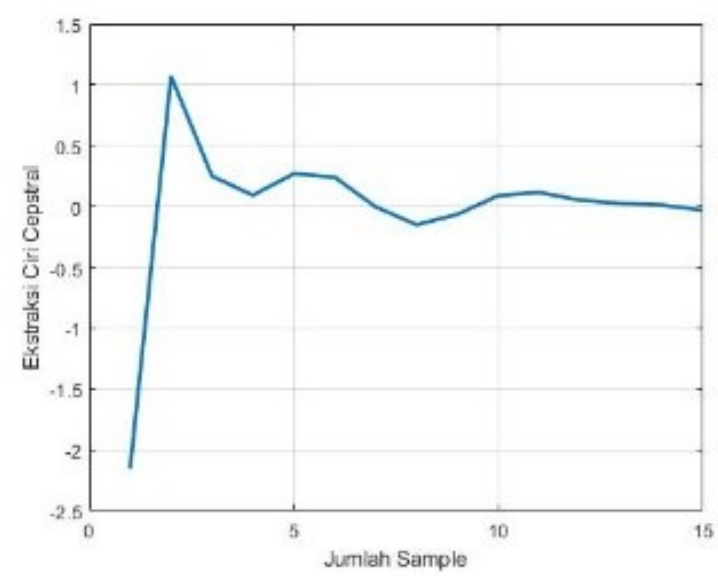

(c)

\section{Gambar 6. Ekstraksi Ciri Analisis Cepstral Berkas} Asli (a), Stego DCT (b), dan Noise AWGN (c).

\subsection{Pengujian Panjang Frame}

Dari analisis sebelumnya telah diketahui bahwa penggunaan overlap dengan nilai koreksi M 100 samples menghasilkan akurasi yang lebih baik. Pada pengujian

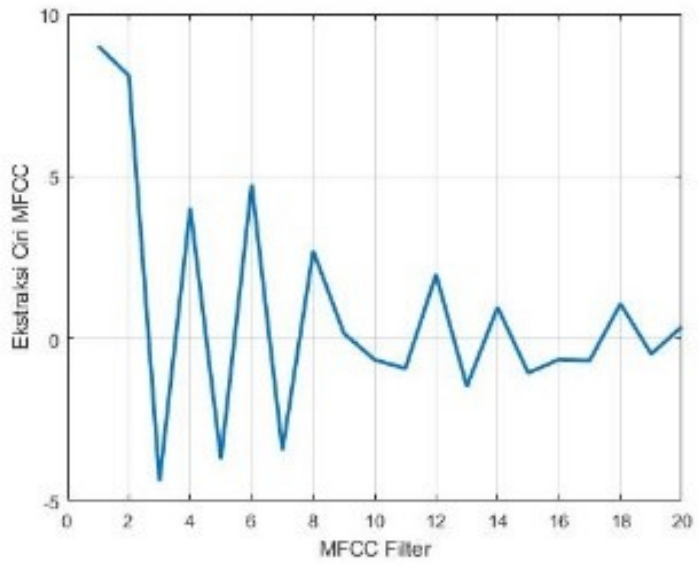

(a)

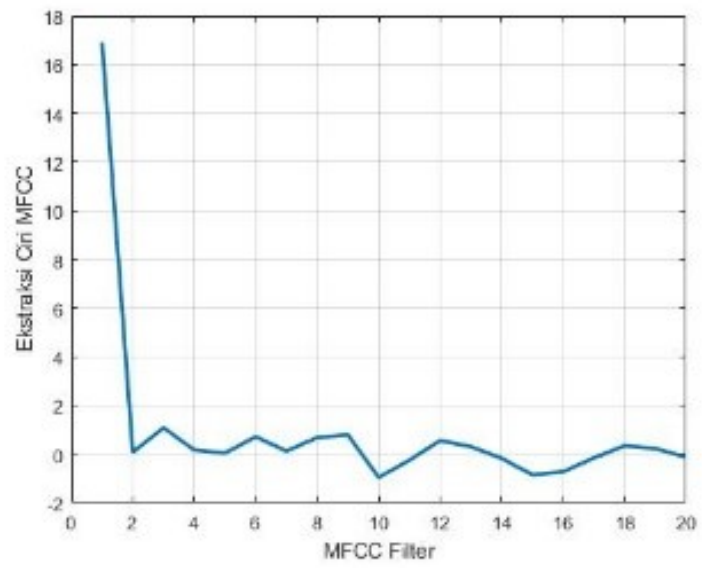

(b)

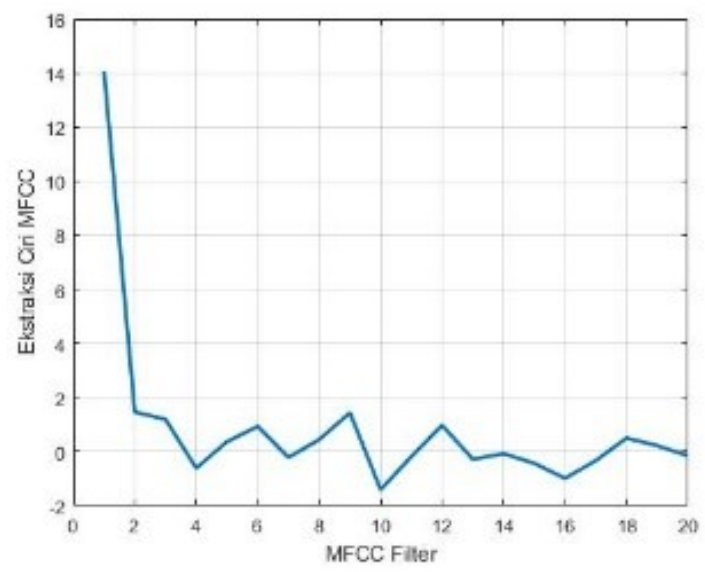

(c)

\section{Gambar 7. Ekstraksi Ciri MFCC Berkas Asli (a),} Stego DCT (b), dan Noise AWGN (c).

kali ini akan dilakukan analisis terhadap panjang frame yang mempengaruhi nilai akurasi. Dilakukan analisis pada panjang frame $30 \mathrm{~ms}, 60 \mathrm{~ms}$ dan $90 \mathrm{~ms}$.

Untuk panjang frame $30 \mathrm{~ms}$ telah dilakukan pada 
pembahasan sebelumnya pada pengujian dengan overlap (Tabel 4.), dengan jumlah frame sebanyak 4786 frames. Jumlah sample dalam satu frame sebanyak 1440 samples. Sedangkan untuk panjang frame $60 \mathrm{~ms}$ didapatkan jumlah frame sebanyak 4772 frames. Jumlah sample dalam tiap frame terdapat 2880 samples, dua kali lipat lebih banyak dibandingkan dengan panjang frame $30 \mathrm{~ms}$. Dan Untuk panjang frame $90 \mathrm{~ms}$ didapatkan jumlah frame sebanyak 4757 frames. Jumlah sample dalam tiap frame terdapat 4320 samples, tiga kali lipat lebih banyak dibandingkan dengan panjang frame $30 \mathrm{~ms}$. Hasil nilai akurasi untuk panjang frame $60 \mathrm{~ms}$ dapat dilihat pada Tabel 5. dan Tabel 6. Untuk panjang frame $90 \mathrm{~ms}$.

Dari ketiga hasil akurasi berdasarkan panjang frame, nilai akurasi yang paling baik untuk kedua metode yang dibandingkan yaitu ketika digunakannya panjang frame $30 \mathrm{~ms}$. Karena kondisi dengan framing atau segmentasi pendek $(10 \mathrm{~ms}-30 \mathrm{~ms})$, bentuk dari nilai vocal tract untuk sinyal wicara relatif tetap sama dengan aslinya.

Gambar 6. menunjukkan bentuk pola ekstraksi ciri analisis cepstral pada frame pertama tiap berkas wicara uji pertama berkas asli (a), stego DWT (b) dan noise AWGN (c). Sedangkan Gambar 7 menunjukkan pola ekstraksi ciri MFCC pada frame pertama tiap berkas wicara uji pertama berkas asli, stego DWT dan noise AWGN. Berdasarkan bentuk pola yang terlihat dari kedua metode, bentuk pola berkas stego dan noise terlihat sekilas serupa dibandingkan bentuk pola berkas asli. Oleh karena itu, akurasi proses klasifikasi berkas stego dan noise dibandingkan berkas asli di setiap parameter uji.

\section{Kesimpulan}

Pada penelitian ini, telah dilakukan pengujian terhadap berkas sinyal wicara menggunakan dua metode, yaitu analisis cepstral dan MFCC dalam beragam parameter, sehingga dapat disimpulkan sebagai berikut:

1. Dari keseluruhan pengujian yang dilakukan dengan metode analisis cepstral, spesifikasi sistem yang paling cocok dengan metode tersebut dan menghasilkan akurasi yang paling baik yaitu dengan menggunakan window hanning, tanpa overlap, dan dengan panjang frame $30 \mathrm{~ms}$ menghasilkan nilai akurasi sebesar $51,11 \%$.

2. Dari keseluruhan pengujian yang dilakukan dengan metode MFCC, spesifikasi sistem yang paling cocok dengan metode tersebut dan menghasilkan akurasi paling baik yaitu dengan menggunakan window hanning, dengan overlap nilai koreksi M 100 samples, dan dengan panjang frame 30ms menghasilkan akurasi sebesar 77,78\%

3. Perbandingan dari kedua metode yaitu analisis cepstral dan MFCC dengan hasil akurasi terbaik yang dimiliki kedua metode, metode yang dapat mendeteksi berkas sinyal wicara merupakan berkas asli, stego ataupun noise lebih baik yaitu metode MFCC berdasarkan nilai akurasi terbaik sebesar $77,78 \%$ karena pada metode MFCC sudah dapat meniru sistem pendengaran manusia dengan cara mengonversi frekuensi rendah dan frekuensi tinggi yang digunakan pada sinyal wicara ke nilai mels, sedangkan untuk analisis cepstral nilai akurasi terbaiknya sebesar $51,11 \%$.

\section{Daftar Pustaka}

[1] H. Liu, J. Liu, R. Hu, X. Yan, and S. Wan, "Adaptive audio steganography scheme based on wavelet packet energy," in Big Data Security on Cloud (BigDataSecurity), IEEE International Conference on High Performance and Smart Computing (HPSC), and IEEE International Conference on Intelligent Data and Security (IDS), 2017 IEEE 3rd International Conference on. IEEE, 2017, pp. 2631.

[2] V. I. Sinisuka, "Steganalisis audio format wav menggunakan metode discrete wavelet transform dan linear discriminant analysis," 2017.

[3] S. Whibley, M. Day, P. May, and M. Pennock, "Wav format preservation assessment," Technical Report. British Library. http://wiki. dpconline. org/images/4/46, Tech. Rep., 2016.

[4] M. Z. Aminudin, "Steganalisis file audio dengan metode statistik mfcc," 2015.

[5] M. Kalamani, D. S. Valarmathy, C. Poonkuzhal, and R. Karthiprakash, "Comparison of cepstral and mel frequency cepstral coefficients for various clean and noisy speech signals," International Journal of Innovative Research in Computer and Communication Engineering, vol. 2, no. 1, p. 28972904, Mar 2014.

[6] A. Wicaksono, S. N. Endah, S. Adhy, and S. Sutikno, "Aplikasi speech recognition bahasa indonesia dengan metode mel-frequency cepstral coefficient dan linear vector quantization untuk pengendalian gerak robot," in Prosiding Seminar Nasional Ilmu Komputer Undip 2014.

[7] M. Likitha, S. R. R. Gupta, K. Hasitha, and A. U. Raju, "Speech based human emotion recognition using mfcc," in Wireless Communications, Signal Processing and Networking (WiSPNET), 2017 International Conference on. IEEE, 2017, pp. 2257-2260.

[8] Y. Rao, C. Vahanesa, C. K. Reddy, and I. M. Panahi, "Two-stage data-driven single channel 
speech enhancement with cepstral analysis preprocessing," in Signal and Information Processing (GlobalSIP), 2015 IEEE Global Conference on. IEEE, 2015, pp. 702-706.

[9] P. Banerjee, B. Chakraborty, and J. Banerjee, "Procedure for cepstral analysis in tracing unique voice segments," in Computing for Sustainable Global Development (INDIACom), 2015 2nd
International Conference on. IEEE, 2015, pp. 351356.

[10] P. A. Octaviani, Y. Wilandari, and D. Ispriyanti, "Penerapan metode klasifikasi support vector machine (svm) pada data akreditasi sekolah dasar (sd) di kabupaten magelang," Jurnal Gaussian, vol. 3, no. 4, pp. 811-820, 2014. 